\title{
Correlation of Sputum Gram Stain and Sputum Culture for Respiratory Tract Infections in a Tertiary Care Hospital, Ballari, India
}

\author{
S. Krishna, Humera Jabeen* and Mariraj Jeer \\ Department of Microbiology, Vijayanagar Institute of Medical Sciences, \\ Ballari 583104, Karnataka, India \\ *Corresponding author
}

\begin{tabular}{|c|c|}
\hline & A B S T R A C T \\
\hline & \multirow{6}{*}{$\begin{array}{l}\text { One of the most important uses of the Gram stain is to evaluate the quality of expectorated } \\
\text { sputum received for routine bacteriological culture. An acceptable sample yields less than } \\
10 \text { squamous epithelial cells per low power field. The simplest and least expensive sample } \\
\text { for the diagnosis of lower respiratory infections is expectorated sputum. The utility of this } \\
\text { approach is the subject of controversy, as the sample is contaminated by oropharyngeal } \\
\text { flora as it passes through the mouth. To evaluate the importance of sputum microscopy and } \\
\text { its correlation with culture in sputum samples from LRTIs and its antibiotic sensitivity } \\
\text { pattern. } 1019 \text { samples were taken for the study. Each stained smear was examined } \\
\text { microscopically, and the cellular components were evaluated. Those samples which } \\
\text { satisfied Bartlett's criteria were processed by standard protocols. According to Bartlett's } \\
\text { screening criteria } 552 \text { (54\%) were accepted and } 467 \text { ( } 46 \%) \text { samples were rejected from } \\
1019 \text { samples. Potential pathogens were recovered from } 450 \text { ( } 81.6 \%) \text { samples out of } 552 \\
\text { accepted samples. The most common organism isolated was Streptococcus pyogenes, } \\
\text { followed by Klebsiella spp., followed by Pseudomonas spp., Staphylococcus aureus, } \\
\text { Escherichia coli, Citrobacter koseri, Enterobacter spp. Most of the isolates were found to } \\
\text { be susceptible to Amikacin, followed by Gentamycin, and most of the isolates were } \\
\text { resistant to Ampicillin. }\end{array}$} \\
\hline Keywords & \\
\hline $\begin{array}{l}\text { Correlation, } \\
\text { Culture, } \\
\text { Respiratory } \\
\text { Infections. }\end{array}$ & \\
\hline Article Info & \\
\hline $\begin{array}{l}\text { Accepted: } \\
\text { 29 May } 2017 \\
\text { Available Online: } \\
\text { 10 June } 2017\end{array}$ & \\
\hline & \\
\hline
\end{tabular}

\section{Introduction}

Lower respiratory tract infections (LRTIs) are a common cause of morbidity and mortality worldwide. For diagnosis of LRTIs, expectorated sputum is the most commonly received sample in the laboratory, which can be obtained easily and non-invasively. Normal resident bacteria of the oropharynx usually contaminate the sputum sample, and a large number of different species overgrow preventing the determination of the true pathogen. One of the most important uses of the Gram stain is to evaluate the quality of expectorated sputum received for routine bacteriological culture. An acceptable sample yields less than 10 squamous epithelial cells per low power field.

The simplest and least expensive sample for the diagnosis of lower respiratory infections is expectorated sputum.

\section{Objective}

To evaluate the importance of sputum microscopy and its correlation with culture in sputum samples from Lower Respiratory 
Tract Infections (LRTIs) and its antibiotic sensitivity pattern.

\section{Materials and Methods}

The study was done from January 2016 to June 2016 at Central microbiology laboratory, VIMS, Ballari. 1019 samples were taken for the study.

Each stained smear was examined microscopically under low power and oil immersion, and the cellular components were evaluated. The samples were inoculated onto Blood agar and Macconkey agar and incubated at $37^{\circ} \mathrm{C}$ for $24 \mathrm{hrs}$.

Depending on the type of growth, various biochemical tests were performed to identify the pathogen.

In vitro Antimicrobial susceptibility testing was done according to CLSI guidelines, by the standard agar disc-diffusion method (Kirby-Bauer) on Mueller Hinton agar.

\section{Results and Discussion}

According to Bartlett's screening criteria 552 (54\%) were accepted and 467 (46\%) samples were rejected from 1019 samples. Potential pathogens were recovered from $450(81.6 \%)$ samples out of 552 accepted samples (Fig. 1).

The most common organism isolated was Streptococcus pyogenes, followed by Klebsiella spp., followed by Pseudomonas spp., Staphylococcus aureus, Escherichia coli, Citrobacterkoseri, Enterobacter spp. Most of the isolates were found to be susceptible to Amikacin, followed by Gentamycin, and most of the isolates were resistant to Ampicillin. Examination of expectorated sputum has been the primary means of determining the causes of bacterial pneumonia. However, lower respiratory tract secretions are always contaminated with upper tract flora present in the saliva.

When potential pathogen is isolated from the sputum sample, it is often difficult to decide whether the potential pathogen is an etiological agent or represents oropharyngeal contamination.

The amount of oropharyngeal contamination can be judged by evaluating the relative number of squamous epithelial cells in the samples.

To minimise the effect of oropharyngeal contamination on lower respiratory tract secretions among cultures, Bartlett, Murray and Washington devised screening criteria based on quantitation of leucocytes and squamous epithelial cells.

Bartlett proposed that purity of sputum samples be rated according to the relative concentration of polymorph nuclear neutrophils, squamous epithelial cells and mucus in gram stained smears.

Average the number of neutrophils and epithelial cells in about 20-30 different 10x microscopic fields and calculate the total. A final score of 0 or less indicates lack of active inflammation or contamination with saliva. Repeat sputum sample should be requested. Grading system for sputum does not apply for lower respiratory tract infections by Legionella species, Mycobacterium tuberculosis, fungi and virus. The importance of micro-organisms recovered from respiratory samples must always be evaluated in light of clinical information. 
Fig.1 Number of samples accepted and rejected
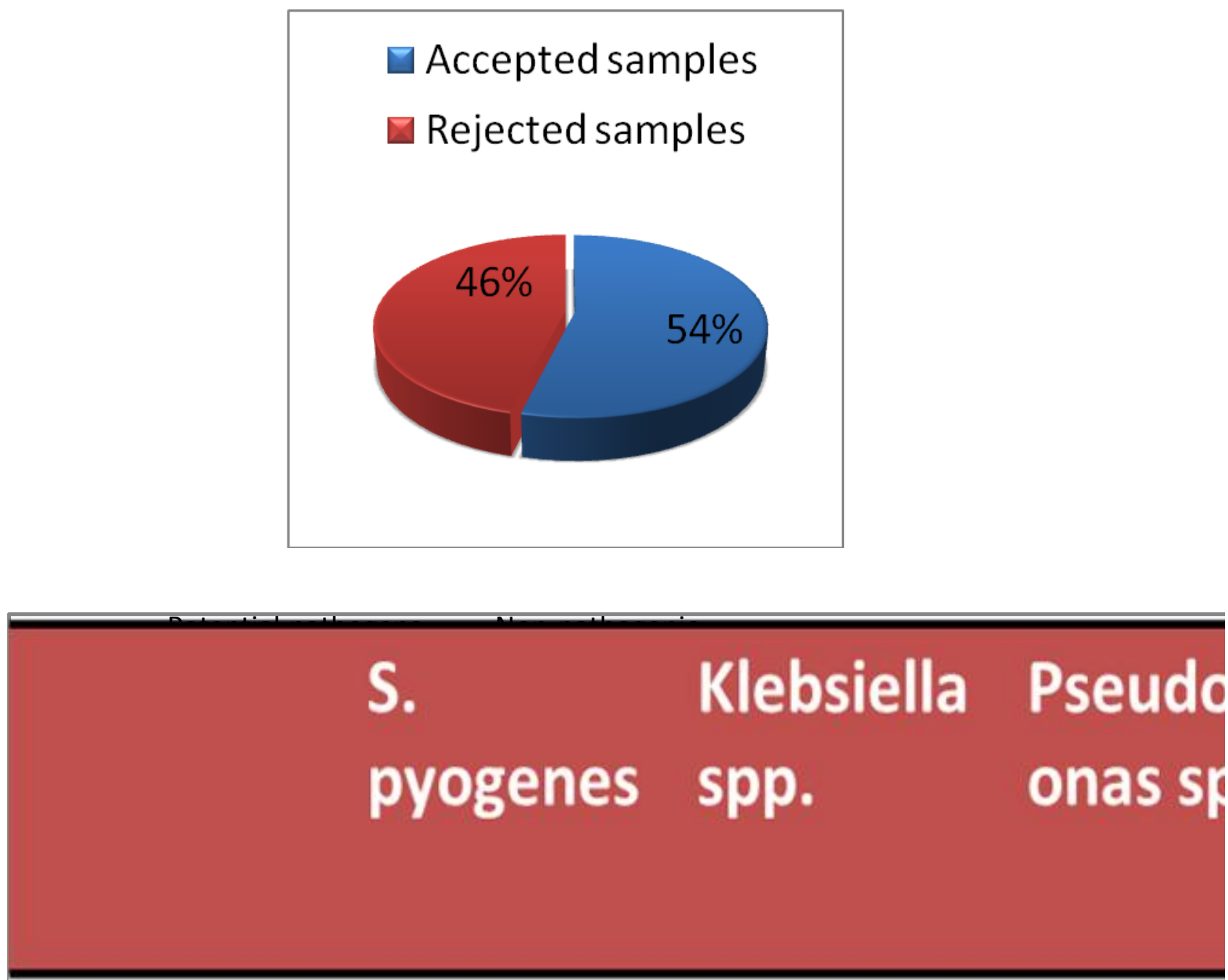
AMIKACIN
$57 \%$
$62 \%$
$58 \%$

GENTAMYCIN

$31 \%$

$40 \%$

$43 \%$

CIPROFLOXACI г[0/

$310 /$

วา0/ 


\begin{tabular}{|l|c|}
\hline Number of Neutrophils/10X LPF & Grade \\
\hline$<10$ & 0 \\
\hline $10-25$ & +1 \\
\hline$>25$ & +2 \\
\hline Presence of mucus & +1 \\
\hline Number of Epithelial cells/10X LPF & -1 \\
\hline $10-25$ & -2 \\
\hline$>25$ & \\
\hline Total Score & \\
\hline
\end{tabular}

In a study conducted by Anuradaha Mokkapatti et al., $65 \%$ samples were acceptable and $35 \%$ were not meeting the standard criteria. Potential pathogens were recovered from $89.74 \%$ acceptable samples, and $9.52 \%$ from non-acceptable samples. In a study conducted by Amudha et al., 42\% were acceptable and 58\% were not meeting the standard criteria. Potential pathogens were obtained from $60.71 \%$ acceptable samples and $39.28 \%$ from non-acceptable samples.

Culture positivity reported in other studies include- Jean J L loveras- 57\%, Daniel Musher et al.,- 79\%, Somporn et al.,- 40.95\%, Nawfal Ali Mubarak- 41.7\%, Aroma Oberoi et al.,- 32\% and Nihan Ziyade et al.,- 44.7\%. On the contrary Ravichandran et al., grew potential pathogens only in 5\% of their specimens processed. The authors had concluded that sputum Gram's stain, sputum culture and blood cultures, in non-severe CAP do not provide any diagnostically useful information and do not help in guiding for initial therapy. They concluded that the tests may be reserved for severe cases of CAP. In the current study 552 (54\%) were accepted and $467(46 \%)$ samples were rejected from 1019 samples. Potential pathogens were recovered from $450(81.6 \%)$ samples out of 552 accepted samples.

Each laboratory should establish criteria for rejection of sputum samples that are not suitable for culture. By applying the criteria, unnecessary sample processing can be avoided, technologist time and workload is reduced. The main aim is to achieve a clinical relevance in Diagnostic Laboratories and provide a meaningful culture report.

\section{References}

Anuradha Mokkapati, Madhavi Yalamanchili. Correlation of Sputum Gram's Stain and Culture in Lower Respiratory Tract Infections. IOSR Journal of Dental and Medical Sciences (IOSRJDMS) e-ISSN: 2279-0853, p-ISSN: 2279-0861. Volume 8, Issue 1 (May. Jun. 2013), PP 06-09.

Aroma Oberoi, Aruna Aggarwal. Bacteriological profile, Serology and Antibiotic Sensitivity Pattern of Micro-organisms from Community Acquired Pneumonia. J K Science, April-June 2006; 8(2): 79-82.

Bindu Nair, Jenny Stapp, Lynn Stapp, Linda Bugni, Jill Van Dalfsen, and Jane L. Burns. 2002. Utility of Gram staining for evaluation of the quality of cystic fibrosis sputum samples. J. Clin. Microbiol. Vol 40. No 8

CLSI Guidelines 2016.

Dr. V. P. Amudha, Dr. B. Cinthujah, Dr. G. Sucilathangam. Sputum Gram Stain Assessment in Relation to Sputum Culture for Respiratory Tract Infections in a Tertiary Care Hospital. Global journal for research analysis. Volume: 3 | Issue: 4 | April 2014 • ISSN No $2277-8160$. 
Jean Jacques L lover as, Mohammed Issam Shukr, Claude Pinos, Anissa L indoulsi, Philippe Grima. 2010. Usefulness of sputum Gramstain and culture for diagnosis of pneumonia in a geriatric institution. Journal of IMAB.

M R Shariatzadeh and T J Marrie. Does sputum culture affect the outcome of community acquired pneumonia? Eastern Mediterranean Health Journal, 2009; 15(4): 792-799.

M Rahman. Quality of specimens and sputum culture results: a retrospective study. Post-Graduate Medical Journal, August 1979; 55: 553-555.

Miriam B Buenvije MD. 1989. Quantitative sputum culture and Gram stain: Pulmonary infection vs colonization. Phil J Microbiology infect dis 1989: 18(1): 28-35.

Nawfal Ali Mubarak. The findings of sputum culture of intubated mechanically ventilated patients versus non intubated patients in the Intensive Care Unit. Basrah Journal of Surgery, September 2012; 18: 1-5.

Ravichandran Theerthakarai, Walid El Halees, Medhat Ismail, Roberto A. Solis, M Anees Khan. Non value of Initial Microbiological Studies in the management of non-severe Community Acquired Pneumonia. Chest, January 2001; 119(1): 181-184.

Washington Winn Jr, Stephen Allen, William Janda, Elmer Koneman. Guidelines for collection, transport, processing, analysis and reporting of cultures from specific specimen sources. In: Koneman's colour atlas and textbook of Microbiology, 6th edition. Lippincott, Williams and Wilkins publications, 2006: 68-111.

\section{How to cite this article:}

Krishna, S., Humera Jabeen and Mariraj Jeer. 2017. Correlation of Sputum Gram Stain and Sputum Culture for Respiratory Tract Infections in a Tertiary Care Hospital, Ballari. Int.J.Curr.Microbiol.App.Sci. 6(6): 3008-3012. doi: https://doi.org/10.20546/ijcmas.2017.606.357 